\title{
Alkaline Phosphatase, Tissue-Nonspecific Isozyme
}

National Cancer Institute

\section{Source}

National Cancer Institute. Alkaline Phosphatase, Tissue-Nonspecific Isozyme. NCI

Thesaurus. Code C104232.

Alkaline phosphatase, tissue-nonspecific isozyme ( $524 \mathrm{aa}, \sim 57 \mathrm{kDa})$ is encoded by the human ALPL gene. This protein may play a role in matrix mineralization. 